\title{
Yield performance of several peanut cultivars grown in dryland with semi-arid climate in Sumba Timur, Indonesia
}

\author{
AGUSTINA ASRI RAHMIANNA ${ }^{*}$, ANDY WIJANARKO, JOKO PURNOMO, YULIANTORO BALIADI \\ Indonesian Legumes and Tuber Crops Research Institute. Jl. Raya Kendalpayak Km. 8, Malang 65162, East Java, Indonesia. Tel.: +62-341-8014868, \\ Fax.: +62-341-801496, `email: anna_rahmianna@yahoo.com
}

Manuscript received: 30 September 2020. Revision accepted: 25 November 2020.

\begin{abstract}
Rahmianna A, Wijanarko A, Purnomo J, Baliadi Y. 2020. Yield performance of several peanut cultivars grown in dryland with semi-arid climate in Sumba Timur, Indonesia. Biodiversitas 21: 5747-5757. Peanut (Arachis hypogaea L.) is the fourth major food crops in Indonesia after rice, maize, and soybean. The seeds contain oil, protein, and carbohydrate which are beneficial to human health. Despite its health benefit, farmers sell all pods for cash. The dryland areas with semi-arid climates, where there is only one growing season, are the potential areas for peanut cultivation. The experiment was conducted to assess the performance of improved cultivars grown in dryland with low rainfall at Sumba Timur District of East Nusa Tenggara Province, Indonesia during February-May 2017. Ten improved peanut cultivars and one local cultivar were grown in two sites: Laipori and Palakahembi Villages. A randomized block design with three replicates was applied in each site. The treatment was peanut cultivar, i.e., Local Sandel, Bison, Gajah, Hypoma 1, Hypoma 2, Kancil, Kelinci, Takar 1, Talam 1, Talam 2, and Tuban that belonged to Spanish type except Kelinci that was a Valencia type. A $100 \mathrm{~kg} \mathrm{ha}^{-1}$ of composite NPK fertilizer was applied at sowing time, and the water source was merely from rainfall. Captan fungicide was applied as seed treatment, and Deltamethrin insecticide were applied two times during the growing period. The results indicated that the improved cultivars performed better than the local cultivar, i.e., their pod yields were 1.75-2.57 times higher than that of Local Sandel. Hypoma 1 cultivar gave the highest yield with $2.313 \mathrm{t} \mathrm{ha}^{-1}$ of dry pod yields or $257 \%$ higher than that of Local Sandel. In addition to high pod yield production, Hypoma 1 also produced $6.1 \mathrm{t} \mathrm{ha}^{-1}$ fresh haulms, and those of improved cultivars were 5.3-7.2 $\mathrm{t}$ $\mathrm{ha}^{-1}$. In summary, the improved cultivars, especially Hypoma 1 is highly recommended for cultivation by the farmers in Sumba Timur because of their high pod yields and organic matter content in soils after the plants harvested.
\end{abstract}

Keywords: Arachis hypogaea, improved cultivars, organic matters, pod yield

\section{INTRODUCTION}

Peanut (Arachis hypogaea L.) is one of the major food crops and the second most important pulse crop after soybean in Indonesia. The popularity of peanuts among Indonesian people is shown by the huge amount (89\%) of available grains that are allocated for human consumption (Pusdatin 2016). The grains are consumed in various types of food such as snacks, cake fillers, and peanut sauce for various dishes, as well as for food industry. It has been known that fat, protein, and carbohydrate contained by the grains are beneficial to human health. In addition to fat and protein, peanut is a nutritional source for vitamins, minerals, antioxidants, and electrolytes and therefore peanut is a complete dietary source (Arya et al. 2016). The fat and protein contents of improved cultivars in Indonesia are reasonably high, i.e., 31 to $53 \%$ and 17.0 to $32.8 \%$ of dw basis, respectively (Balitkabi 2016). In spite of its health benefit, farmers sell almost all pods to get cash money. This is the reason why peanut is a cash crop for smallholder farmers in Indonesia and many African countries such as Zimbabwe (Homann-Kee Tui et al. 2012), Tanzania (Katundu et al. 2014), and Sinegal (Sene 2015).

High demand for peanut for human consumption however is followed by the reduction of annual peanut production from 605.449 tones $(\mathrm{t})$ to $420.099 \mathrm{t}$ in the period of 2015-2019 because of the decline of both the harvest areas from 454.349 to 332.883 hectares (ha), and productivity from 1.333 to $1.262 \mathrm{t} \mathrm{ha}^{-1}$ at the same period (Ditjentan 2020). The Government, therefore, imported peanut grains from overseas to meet the national demand. Until recently, the demand for peanuts has been met both from domestic production and imported grains.

To reduce the amount of imports, the Government of Indonesia increases national production by extending the planting areas of peanuts. The targeted areas are several potential areas such as drylands with acidic soil conditions, tidal swamp areas, and drylands with semi-arid climate. Drylands with acidic soil conditions are mostly located in western part of Indonesia as well as Papua in eastern Indonesia with a wetter climate type and high annual rainfall. The drylands with acidic soil conditions occupy around 107 million ha but only around 62.6 million ha are potential for agriculture development. At the present time, oil palm and rubber tree crops along with food crops especially maize, cassava, and soybean are the dominant crops grown by farmers in that acidic drylands. Peanuts have not been vastly developed in this dryland.

There is 7.7 million ha of drylands with semi-arid climate that is suitable for agriculture activities, where 3 million ha are located in East Nusa Tenggara (NTT) Province, Indonesia (Dariah and Heryani 2014). Drylands with semi-arid climate types in this province are the potential lands for food crops, i.e.. maize, peanuts, 
mungbean, to lesser extent for cassava and sweet potato, and the least extent for soybean. At the national level, NTT Province is in the $6^{\text {th }}$ rank of the biggest peanut production in Indonesia. One central production area for peanuts in NTT is Sumba Timur District located in Sumba Island.

Sumba Island has a semi-arid climate type with short rainy season that lasts only for four months (December to March) with total annual rainfall of $547 \mathrm{~mm}$ up to 1100 $\mathrm{mm}$ during the period of 2011-2018 (BPS Sumba Timur 2012, 2013, 2014, 2015, 2016, 2017, 2018). In Sumba Timur, peanut is intercropped with maize and sorghum. Maize and sorghum serve as staple food crops, and peanuts as cash crops (BPS Sumba Timur 2018). These crops are annual crops with around 3 months growing season, and grown simultaneously in early wet season. The short period of wet season with low rainfall results in limited water availability for those food crops. Drought stress during later growing season is almost occurring every year.

Famers grow peanuts following the traditional cultural practices, i.e., soil tillage, preemergence herbicide application, regular plant spacing, sowing in hole with 1-4 seeds hole $^{-1}$, local cultivar, no fertilization, no pesticide application, once weeding at around 15 days after sowing. These simple practices give low pod yield of 1.1 to $1.2 \mathrm{tha}$ 1 (Rahmianna 2015). The short rainy season in Sumba Timur enables only one cropping season. After the crops are harvested, farmers leave maize and sorghum stover as well as peanut haulm in the fields and never been provided to the cattle as in NTT, including Sumba Timur, the cattle are generally are raised by free grassing in savanna areas. Peanut haulms contain higher crude fiber, total digestible $\mathrm{N}$ (TDN), and dry matter than those of soybean and mungbean haulms, cassava leaves, and its tuber peels, as well as sweet potato tubers (Prawiradiputra and Lukiwati 2014). Among those parameters, crude protein was the main trait in evaluating the groundnut lines suitable for pod and haulm yields (Oteng-Frimpong et al. 2017).

Once the peanut greens are left in the fields as crop residues, it will naturally decompose after sometimes (several days to months) depends on the environmental condition of the fields. Under dry environment, the decomposition of crop residues (roots, stems, and foliages) takes months. The fallow period after crop harvest give a good impact on soil fertility as the crop residues are the major source of organic materials (carbon-based) that builds soil organic matter. Besides carbon, peanut residue also contains nitrogen deposited in root nodules. This is one obvious benefit so that $\mathrm{C}$-organic content of the soils is high after the decomposition of peanut crop residues.

The Gov. of Indonesia has released at least 45 improved peanut cultivars since 1950's with various resistance characters to abiotic and biotic stresses. The average productivity of these cultivars is from $1.8-3.5 \mathrm{t} \mathrm{ha}^{-1}$ of dry pods, with drought-tolerant cultivars have average pod yields of $1.44-2.6 \mathrm{t} \mathrm{ha}^{-1}$ (Balitkabi 2016). This indicates that there is an opportunity to improve local production by growing high yielding cultivars. Therefore, a critical analysis of genetic variability of the improved cultivars under the existing environmental condition is an important step to initiate the improvement of peanut production in
Sumba Timur. The application of improved cultivar with high yield potential is the easiest way for farmers to adopt the technology. To increase production and productivity of peanuts in drylands with semi-arid climates in Sumba Timur, improved cultivars have to be introduced. These cultivars actually are bred in the optimum agro-ecologies, i.e., in central production areas with wetter climates. The objective of the research, therefore, was to assess the pod yields of improved peanut cultivars under the agro-ecology of dryland with semi-arid climate of Sumba Timur.

\section{MATERIALS AND METHODS}

The experiment was conducted in drylands with low rainfall at Sumba Timur District, East Nusa Tenggara (NTT) Province, Indonesia during the planting season of FebruaryMay 2017. Ten improved peanut cultivars and one local cultivar were grown at two sites: Laipori (latitude $9^{\circ} 37^{\prime} 47^{\prime \prime}$ S, longitude 120'27'00' E) and Palakahembi (latitude 9'37'34' S, longitude $120^{\circ} 27^{\prime} 05^{\prime \prime}$ E) villages in the Sub-district of Pandawai. A randomized block design with three replicates was applied in each site. The treatment was cultivar: Local Sandel (local cultivar), Bison, Gajah, Hypoma 1, Hypoma 2, Kancil, Kelinci, Takar 1, Talam 1, Talam 2, and Tuban (improved cultivars) that belong to Spanish type except for Kelinci that is a Valencia type. Each cultivar was sown in a $4 \mathrm{~m} \times 4 \mathrm{~m}$ plot size, plant spacing of $40 \mathrm{~cm} \times 10 \mathrm{~cm}$ with one seed/hole. Prior to sowing, the seeds were treated with fungicide Captan at the rate of $10 \mathrm{~g}$ of Captan per $1 \mathrm{~kg}$ of seeds. Land preparation consisted of plowing to obtain friable soil, applying herbicide at 5 days before sowing, preparing plots and drainage canal among the plots. An amount of $100 \mathrm{~kg} \mathrm{ha}^{-1}$ of composite NPK fertilizer (contained $15 \% \mathrm{~N}, 15 \% \mathrm{P}$, and $15 \% \mathrm{~K}$ ) was broadcasted onto the plots after sowing the seeds. Water requirement for the crops was obtained merely from rainfalls. Deltamethrin insecticide was applied two times during the growing period. Weeding was conducted once at 45 DAS. The observation was undertaken on pod yield and yield components. The yield components were observed at 10 sampling plants that were randomly taken in each plot at harvesting time. Pod yield per hectare was determined based on pod yields from all harvested plants in one plot. Pods were ripped from the plants and sun-dried for 5-7 days.

All data were then subjected to analysis of variance using a statistical program of MStatC 1.4 version developed by Crop and Soil Sciences Department, Michigan State University. The parameters that were significantly different $(\mathrm{p}<0.05)$ were then subjected to a Duncan Multiple Range Test (DMRT) to find out the differences among the means of cultivars tested. The variance contribution of treatments was calculated based on Savemore et al. (2017a):

$$
\begin{aligned}
& \text { Variance contribution of } \mathrm{G}=\frac{\mathrm{SSg}}{\sum(\mathrm{SSg}+\mathrm{SSl}+\mathrm{SSg} \times \mathrm{l})} \times 100 \% \\
& \text { Variance contribution of } \mathrm{L}=\frac{\mathrm{SSl}}{\sum(\mathrm{SSg}+\mathrm{SSl}+\mathrm{SSg} \times \mathrm{l})} \times 100 \% \\
& \text { Variance contribution of } \mathrm{G} \times \mathrm{L}=\frac{\mathrm{SSg} \times \mathrm{L}}{\sum(\mathrm{SSg}+\mathrm{SSl}+\mathrm{SSg} \times \mathrm{l})} \times 100 \%
\end{aligned}
$$


Where:

G : Genotype

L : Environment (=site, location)

SSg : Sum of square of genotype

SS1 : Sum of square of environment

SSgxl: Sum of square genotype and environment interaction

\section{RESULTS AND DISCUSSION}

\section{Weather condition during experiment}

The information on weather data during experiment in 2017 was obtained from the nearest meteorology station which is located around $20 \mathrm{~km}$ from experimental sites. The amount of rainfall in Sumba Timur during the growing season (446.1 $\mathrm{mm}$ in 51 rainy days) (Table 1) did not support the ideal plant growth. Good rains occurred only in the first month of the growing season, and was then insufficient in the following months to support a good peanut crop growth. Rahmianna et al. (2015) summarized several studies in Indonesia emphasizing that rainfall should be distributed at least into 80 rainy days for good growth and pod yield of peanut, and the reduction into 50 rainy days significantly reduced pod yield by $50 \%$.

Peanut plants prefer clear days with high sunshine intensity of $>45 \%$ for optimal growth and development. Low sunlight intensity, however, will reduce vegetative growth, promote flower abortion, and reduce the pod number (Variath and Janila 2017). In Laipori and Palakahembi growing sites, the sunlight intensity was high, especially during generative growth stage, and at the same time, the rainfall was low (Table 1). These conditions depreciated the crops growth, even though high sunshine radiation during gynophores formation to maturity was positively correlated with pod yield (Canavar and Kaynak 2010).

\section{Summary statistics and analysis of variance}

The mean, minimum, and maximum values of pod yield and agronomic performance of 11 genotypes over 2 locations were presented in Table 2. The highest dry pod yield was $2.313 \mathrm{t} \mathrm{ha}^{-1}$ and the lowest was $0.901 \mathrm{t} \mathrm{ha}^{-1}$ with an average yield of $1.773 \mathrm{t} \mathrm{ha}^{-1}$. The lowest and the highest numbers of mature pods plant ${ }^{-1}$ were 8.7 pods and 13.5 pods, respectively. Whilst mean pod yield plant ${ }^{-1}$ was 13.9 $\mathrm{g}$ with $15.4 \mathrm{~g}$ and $11.2 \mathrm{~g}$ as the highest and the lowest yields, respectively. Number of branches plant ${ }^{-1}$ ranged from 5.1 to 7.9 with a mean of 6.3 branches (Table 2). A 100 -seed weight ranged from $26.7 \mathrm{~g}$ to $53.0 \mathrm{~g}$ with six

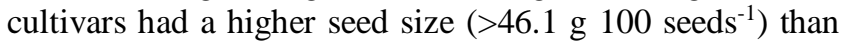
average and the rest five cultivars with lower seed size than average. Average number of mature pods plant $^{-1}$ was 10.2 with only four cultivars had more than 10 pods plant ${ }^{-1}$ and the other seven cultivars had lower than 10.2 pods plant ${ }^{-1}$ (Figure 1). Weight of mature pods plant ${ }^{-1}$, shelling percentage, and 100-seed weight of three (Local Sandel, Hypoma 1, and Kancil) out of 11 cultivars were higher than the mean value of those parameters (Figure 1). This means that these three cultivars had good generative growth especially in terms of their yield components. Conversely, most cultivars had poor vegetative growth, i.e., plant height, and fresh haulm weight as only four cultivars grew better than the average (Figure 1).

Table 1. Weather data of Sumba Timur from February to May 2017

\begin{tabular}{lccccccc}
\hline \multicolumn{1}{c}{ Month } & $\begin{array}{c}\text { Rainy } \\
\text { days }\end{array}$ & $\begin{array}{c}\text { Rainfall } \\
(\mathbf{m m})\end{array}$ & $\begin{array}{c}\text { Min air temp } \\
\left({ }^{\circ} \mathbf{C}\right)\end{array}$ & $\begin{array}{c}\text { Max air temp } \\
\left({ }^{\circ} \mathbf{C}\right)\end{array}$ & $\begin{array}{c}\text { Mean temp } \\
\left({ }^{\circ} \mathbf{C}\right)\end{array}$ & $\begin{array}{c}\text { Mean RH } \\
(\boldsymbol{\%})\end{array}$ & $\begin{array}{c}\text { Mean sunshine } \\
(\boldsymbol{\%})\end{array}$ \\
\hline February & 18 & 231.9 & 22.0 & 32.8 & 27.1 & 83 & 58.2 \\
March & 16 & 138.4 & 23.0 & 34.6 & 27.5 & 83 & 58.1 \\
April & 16 & 72.8 & 21.1 & 34.0 & 27.3 & 82 & 80.0 \\
May & 1 & 3.0 & 20.0 & 33.6 & 27.4 & 75 & 79.5 \\
\hline
\end{tabular}

Source: Mau Hau Class III Meteorology Station, Waingapu, Sumba Timur

Table 2. Mean, minimum and maximum values of pod yield and yield components, and agronomic parameters from two locations

\begin{tabular}{|c|c|c|c|c|}
\hline \multirow{2}{*}{ Parameter } & \multirow{2}{*}{ Mean \pm SE } & \multicolumn{2}{|c|}{ Range } & \multirow{2}{*}{ SD } \\
\hline & & Min & Max & \\
\hline Number of branches (plant ${ }^{-1}$ ) & $6.3 \pm 0.23$ & 5.1 & 7.9 & 0.77 \\
\hline Plant height $(\mathrm{cm})$ & $28.1 \pm 0.49$ & 24.5 & 30.4 & 1.62 \\
\hline Fresh haulm yield $\left(\mathrm{t} \mathrm{ha}^{-1}\right)$ & $6.2 \pm 0.21$ & 4.9 & 7.2 & 0.71 \\
\hline Fresh pod yield $\left(\mathrm{t} \mathrm{ha}^{-1}\right)$ & $2.147 \pm 0.11$ & 1.369 & 2.735 & 0.35 \\
\hline Dry pod yield (12\% MC) $\left(\mathrm{t} \mathrm{ha}^{-1}\right)$ & $1.773 \pm 0.12$ & 0.901 & 2.313 & 0.40 \\
\hline No of harvested plants $\left(\right.$ ha $\left.^{-1}\right)$ & $233,455 \pm 11,973$ & 122,667 & 262,167 & $39,709.85$ \\
\hline No of mature pods (plant ${ }^{-1}$ ) & $10.2 \pm 0.42$ & 8.7 & 13.5 & 1.38 \\
\hline No of immature pods (plant ${ }^{-1}$ ) & $2.1 \pm 0.21$ & 1.5 & 3.9 & 0.70 \\
\hline Mature pod weight $\left(\mathrm{g} \mathrm{plant}^{-1}\right)$ & $13.9 \pm 0.54$ & 11.2 & 15.4 & 1.80 \\
\hline Seed weight $\left(\mathrm{g} \mathrm{plant}^{-1}\right)$ & $8.4 \pm 0.34$ & 7.1 & 10.5 & 1.12 \\
\hline Shelling percentage $(\%)$ & $61.2 \pm 0.71$ & 57.6 & 65.6 & 2.35 \\
\hline 100 seed weight $(\mathrm{g})$ & $44.1 \pm 2.23$ & 26.7 & 53.0 & 7.40 \\
\hline
\end{tabular}



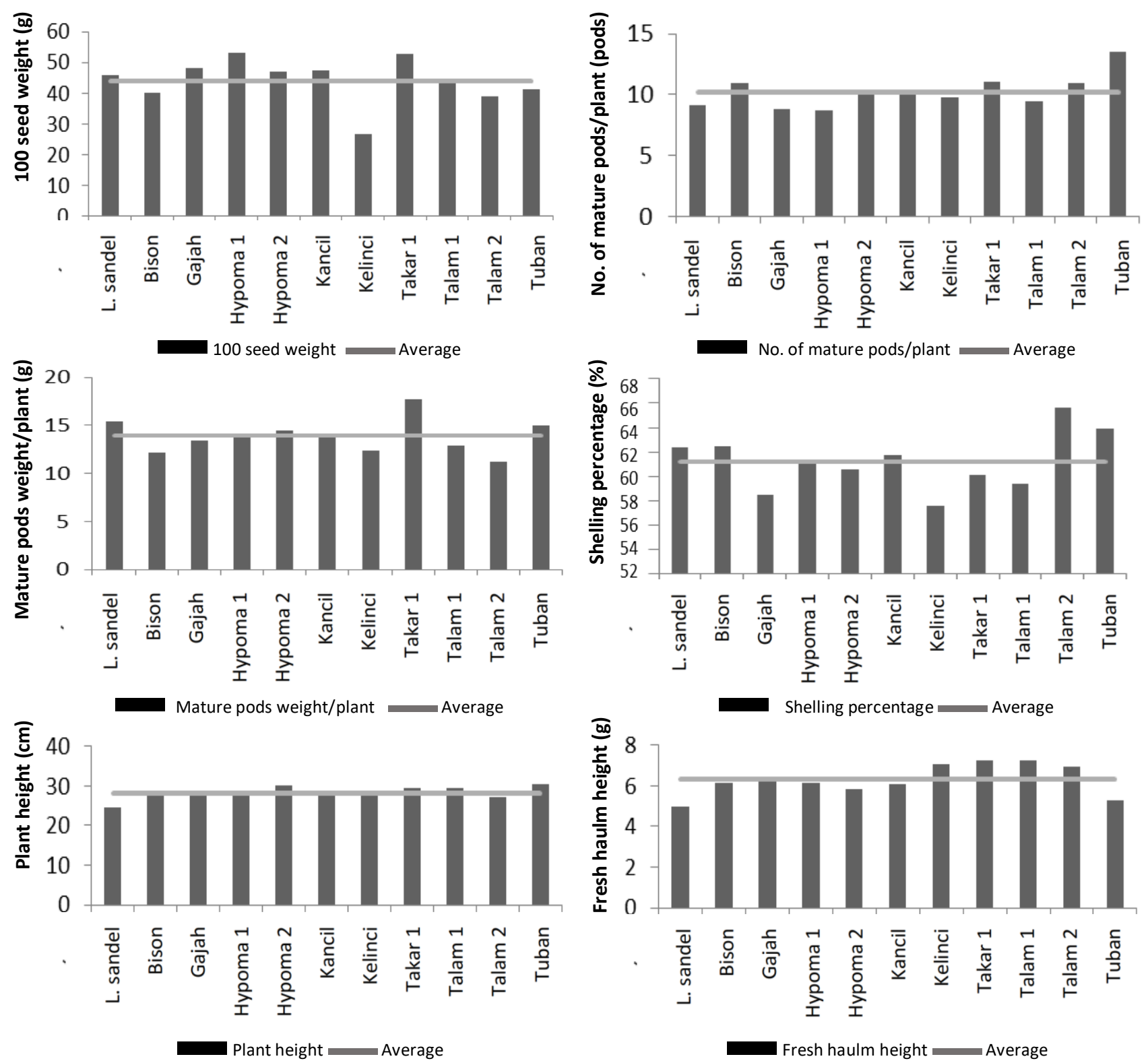

Figure 3. Yield and vegetative growth components of 11 cultivars compared to its average across two sites

The mean yield and yield component performances of 11 peanut cultivars over two growing sites included $1.773 \mathrm{t}$ ha $^{-1}$ of pod yield (13.9 g pod yield plant $\left.{ }^{-1}\right), 10.2$ mature pods plant ${ }^{-1}, 61.2 \%$ shelling percentage, and $44.1 \mathrm{~g}$ of 100 seed weight. As a comparison, Oteng-Frimpong et al. (2017) obtained pod yield of $2.76 \mathrm{t} \mathrm{ha}^{-1}$ with contributing parameters of 31 pods plant $^{-1}, 63.2 \%$ of shelling percentage, and $35.7 \mathrm{~g}$ of 100 -seed weight. It can be seen that pod yield was ultimately affected by mature pod yield plant $^{-1}$, number of mature pods plant ${ }^{-1}$, shelling percentage, and seed size (100-seed weight). This result was in line with the work undertaken by Janila et al. (2013).

Combined analysis of variance showed that location (L), genotype $(\mathrm{G})$, and $\mathrm{G} \times \mathrm{L}$ interaction either individually or together significantly affected pod yield, and all growth parameters observed except for seed weight plant ${ }^{-1}$ (Table
3). Location significantly affected plant height, fresh haulm yield, no. of immature pods plant ${ }^{-1}$, mature pods weight plant $^{-1}$, and shelling percentage. The dominance of location as variance contributor was expressed in plant height, fresh haulm weight hectare ${ }^{-1}$, no. of immature pods plant $^{-1}$, mature pods weight plant ${ }^{-1}$, and shelling percentage with 80.6, 74.5, 64.2, 53.2, and 87.7\%, respectively (Table 3). This means that location was the main contributor to those parameters variations. The dominance of environment factor to plant height, mature pod weight plant $^{-1}$, no. of immature pods plant ${ }^{-1}$ on peanut was also reported by Purnomo et al. (2019). The dominance of location factor on biomass was also reported by Oteng-Frimpong and Dakora (2018) from their multi-environment testing (MET) of 21 genotypes at 6 environments under harsh environmental conditions of Guinea savanna of Ghana. 
Genotype (G) factor significantly influenced no. of branches, pod yield (both dry and fresh pods), and its yield components, i.e., no. of mature and immature pods plant ${ }^{-1}$, mature pods weight plant $^{-1}$, and 100 -seed weight. The significant genotypic $(\mathrm{G})$ variance of pod yield and yield components indicates the presence of variability in the tested genotypes. Number of branches, fresh and dry pods yield hectare ${ }^{-1}$, no. of harvested plants, no. of mature pods plant $^{-1}$, and 100 seed weight were dominantly affected by genotypes which explained 53.6, 88.8, 80.6, 75.4, 54.0, and $83.7 \%$ of total variation, respectively. This genotypic dominance explained that genotype was the main contributor to pod yield variation in two locations. The dominance of genotypes on pod yield was also reported by Dolinassou et al. (2016) who worked with 13 genotypes tested in three locations. These studies show the presence of diversity of tested genotypes with large differences among mean pod yields of the tested genotypes. On the contrary, Savemore et al. (2017b) reported the significant influence of environment on pod yield from evaluation trials of 25 genotypes at five environments.

The interaction effect of $\mathrm{L} \times \mathrm{G}$ was significant for number of branches and 100-seed weight (Table 3). The presence of these interactions indicates the different responses among genotypes in those parameters to the changes of environments as reported by Dabessa et al. (2016) for multi-environmental tests of nine genotypes. It can be informed here that genotype factor was driving more variation than its location factor in both parameters. These are indicated by $53.6 \%$ and $83.7 \%$ of genotypic variance contribution, compared to $16.8 \%$ and $4.8 \%$ of location variance contribution. In addition, the $\mathrm{G} \times \mathrm{L}$ variation was dominant only in seed weight plant $^{-1}$ that accounted for $47.1 \%$ (Table 3). The least $\mathrm{G} \times \mathrm{L}$ interaction in tested parameters indicated the lesser significant roles of biotic and abiotic factors in the studied areas on yield, yield components, and plant growth parameters.

\section{Pod yield}

The range of dry pod yields of 11 cultivars was from 0.91 to $2.3 \mathrm{tha}^{-1}$ under dry condition of growing sites in
Sumba Timur, despite of higher average yields, i.e, 1.7 to $3.0 \mathrm{t} \mathrm{ha}^{-1}$ when the cultivars were grown under optimum condition of multi-environment testings (MET) (Balitkabi 2016). In general, pod yield of every cultivar in Sumba Timur was lower compared to their average yield obtained from MET except for Kancil cultivar (Table 4). This is because their genetic yield potentials had not been obtained under unfavorable environments, i.e., drought stress. This finding was similar to the work done by Kebede and Getahun (2017).

In the current study, yield performances of all cultivars grown in Laipori were better than those in Palakahembi, except those of Hypoma 2, Kelinci, Talam 1, Tuban that produced a higher yield in Palakahembi (Table 4). This means that each cultivar had certain adaptation to the site condition of either Laipori or Palakahembi. Comparing pod yields of tested cultivars that were obtained under dry climate at Sumba Timur and wetter conditions during MET, pod yields of cultivars Bison, Gajah, and Kelinci were slightly reduced by $5.5-7 \%$. Moreover, cultivars Hypoma 2, Takar 1, and Talam 1 had myriad reduction by $30.8-34.5 \%$ (Table 4). The yield of Gajah and Kancil cultivars obtained in Sumba Timur in current study was similar to those obtained Timor and Rote Islands in the NTT Province, the sites with a similar semi-arid climatic condition. Bison cultivar, however, obtained better yield in Sumba Timur compared to that in Timor and Rote Islands (Mau et al. 2014). The Island of Sumba (where Sumba Timur located), Timor, and Rote are three islands that are closely located one to each other. Koolachart et al. (2103) also reported pod yield reduction of $38-42 \%$ when the peanut crop had terminal drought stress (drought stress started at R7 growth phase and continues to harvest). This yield reduction could be contributed by the reduction of $\mathrm{N}$, $\mathrm{P}, \mathrm{K}, \mathrm{Mg}, \mathrm{Ca}$ uptake as a result of decreasing soil water availability, and this is genotype-specific. It was also reported by Htoon et al. (2014) that drought-tolerant genotypes could maintain high nutrient uptake both under well and reduced water conditions.

Table 4. Dry pod yields of cultivars tested in two locations and its average yields of Sumba Timur (Indonesia) trials, and dry pod yields of cultivars obtained from multi-environment testings, and yield differences between average yield from multi-environment testings and trials

\begin{tabular}{|c|c|c|c|c|c|}
\hline Cultivars & $\begin{array}{c}\text { L 1: } \\
\text { Laipori } \\
\left(t \text { ha }^{-1}\right)\end{array}$ & $\begin{array}{c}\text { L2: } \\
\text { Palaka Hembi } \\
\left(\mathrm{t} \mathrm{ha}^{-1}\right)\end{array}$ & $\begin{array}{c}\text { Average } L 1 \text { and } L 2 \\
\left(\mathrm{t} \mathrm{ha}^{-1}\right) \\
(\mathrm{A})\end{array}$ & $\begin{array}{c}\text { Average MET } \\
\left.\left(\mathbf{t ~ h a}^{-1}\right)^{* *}\right) \\
(\mathrm{B})\end{array}$ & $\begin{array}{c}\text { Yield difference } \\
\text { compared to MET }(\%) \\
(\mathrm{B}-\mathrm{A}) / \mathrm{B}\end{array}$ \\
\hline L. sandel & 1.057 & 0.745 & $0.901 \mathrm{f}$ & 2.2 & 59.0 \\
\hline Bison & 1.962 & 1.761 & $1.861 \mathrm{cde}$ & 2.0 & 7.0 \\
\hline Gajah & 1.889 & 1.505 & $1.697 \mathrm{de}$ & 1.8 & 5.7 \\
\hline Hypoma 1 & 2.546 & 2.079 & $2.313 \mathrm{a}$ & 2.3 & -0.6 \\
\hline Hypoma 2 & 1.442 & 1.705 & $1.573 \mathrm{e}$ & 2.4 & 34.5 \\
\hline Kancil & 2.427 & 2.050 & $2.238 \mathrm{ab}$ & 1.7 & -31.6 \\
\hline Kelinci & 2.055 & 2.294 & $2.174 \mathrm{abc}$ & 2.3 & 5.5 \\
\hline Takar 1 & 1.658 & 1.593 & $1.626 \mathrm{de}$ & 3.0 & 45.8 \\
\hline Talam 1 & 1.546 & 1.636 & $1.591 \mathrm{de}$ & 2.3 & 30.8 \\
\hline Talam 2 & 1.962 & 1.889 & $1.926 \mathrm{bcd}$ & 2.3 & 16.3 \\
\hline Tuban & 1.542 & 1.664 & $1.603 \mathrm{de}$ & 2.0 & 19.9 \\
\hline Average & 1.826 & 1.720 & $1.773 *$ & & \\
\hline
\end{tabular}

Note: Numbers in a column followed by similar letters did not significantly different at $\mathrm{p}=0.05$, * significant at $5 \%$, **) MET: multienvironment testings as mentioned in Balitkabi (2016) 
Table 3. Mean square, sum of square, and variance contribution of location (L), genotype $(\mathrm{G})$, and $\mathrm{G} \times \mathrm{L}$ on yield, yield components, and growth variables. Sumba Timur, growing season February-May 2017.

\begin{tabular}{|c|c|c|c|c|c|c|c|c|c|c|c|}
\hline & \multicolumn{3}{|c|}{ Mean square } & \multirow{2}{*}{ CV } & \multicolumn{3}{|c|}{ Sum of square } & \multirow[b]{2}{*}{ Total } & \multicolumn{3}{|c|}{ Variance contribution } \\
\hline & $\mathbf{L}$ & G & $\mathbf{G} \times \mathbf{L}$ & & $\mathbf{L}$ & G & $\mathbf{G} \times \mathbf{L}$ & & $\mathbf{L}$ & G & $\mathbf{G} \times \mathbf{L}$ \\
\hline No branches & $11.21^{\mathrm{ns}}$ & $3.58 * *$ & $1.98 * *$ & 11.95 & 11.21 & 35.76 & 19.804 & 66.774 & 16.8 & 53.6 & 29.7 \\
\hline Plant height & $973.67 * *$ & $15.85^{\mathrm{ns}}$ & $7.65^{\mathrm{ns}}$ & 14.51 & 973.67 & 158.461 & 76.461 & 1208.592 & 80.6 & 13.1 & 6.3 \\
\hline Fresh haulm yield per hectare & $172.40 *$ & $3.14^{\mathrm{ns}}$ & $2.76^{\mathrm{ns}}$ & 22.97 & 172.401 & 31.359 & 27.567 & 231.327 & 74.5 & 13.6 & 11.9 \\
\hline Dry pod yield (12\% MC) & $0.19^{\mathrm{ns}}$ & $0.95^{* *}$ & $0.10^{\mathrm{ns}}$ & 14.59 & 0.185 & 9.535 & 1.021 & 10.741 & 1.7 & 88.8 & 9.5 \\
\hline Fresh pod yield per hectare & $0.26^{\mathrm{ns}}$ & $0.73 * *$ & $0.15^{\mathrm{ns}}$ & 14.57 & 0.261 & 7.292 & 1.496 & 9.049 & 2.9 & 80.6 & 16.5 \\
\hline No harvested plants & $23902.06^{\mathrm{ns}}$ & $9461.27 * *$ & 691.43 & 14.36 & 23902.06 & 94612.7 & 6914.273 & 125429 & 19.1 & 75.4 & 5.5 \\
\hline No of mature pods plant ${ }^{-1}$ & $3.32^{\mathrm{ns}}$ & $11.48 *$ & $9.44^{\mathrm{ns}}$ & 21.15 & 3.319 & 114.827 & 94.441 & 212.587 & 1.6 & 54.0 & 44.4 \\
\hline No immature pods plant ${ }^{-1}$ & $94.56 * *$ & $2.95 * *$ & $2.32^{\mathrm{ns}}$ & 41.90 & 94.561 & 29.467 & 23.223 & 147.251 & 64.2 & 20.0 & 15.8 \\
\hline Mature pod weight plant $^{-1}$ & $400.59 *$ & $19.49^{*}$ & $15.73^{\mathrm{ns}}$ & 21.07 & 400.587 & 194.915 & 157.266 & 752.768 & 53.2 & 25.9 & 20.9 \\
\hline Seed weight plant ${ }^{-1}$ & $15.23^{\mathrm{ns}}$ & $7.49^{\mathrm{ns}}$ & $8.02^{\text {ns }}$ & 25.22 & 15.226 & 74.935 & 80.236 & 170.397 & 8.9 & 44.0 & 47.1 \\
\hline Shelling percentage & $3928.56 * *$ & $33.27^{\mathrm{ns}}$ & $22.07^{\mathrm{ns}}$ & 7.69 & 3928.555 & 332.648 & 220.722 & 4481.925 & 87.7 & 7.4 & 4.9 \\
\hline 100 seed weight & $186.68^{\mathrm{ns}}$ & $328.40 * *$ & $45.09 *$ & 9.84 & 186.682 & 3284.036 & 450.915 & 3921.633 & 4.8 & 83.7 & 11.5 \\
\hline
\end{tabular}

Note: L: Location, G: genotype, G×L: interaction L and G, CV: coefficient variation, ** and * different at 1 and 5\% level of confidence, ns: non significant 
The outstanding cultivars were Hypoma 1 and Kancil with pod yields similar and even higher (0.6 and $31.6 \%$ higher, Table 4) than its average yields from MET. It means that these two cultivars easily adapted to the dry areas with terminal drought stress situations. It may be useful to mention here, that the average yield, as stated in the cultivar description (Balitkabi 2016), were the average dry pod yield obtained from multi-environmental testings (MET) of the candidate cultivars. All improved cultivars had at least six MET at the peanut production center areas, all of which are located in the wetter climate type in western parts of Indonesia.

The yield performance of Local Sandel cultivar was poor as its pod yield in the current experiment was much lower than that of its potential yield, despite this cultivar has been well adapted to the local condition. All improved cultivars produced pod yields $175-257 \%$ higher than that of Local Sandel. Hypoma 1 produced the highest pod yield, followed by Kancil, Talam 2, and Tuban cultivars. Although all tested cultivars were grown at the same time and received similar cultural practices, the pod yields they produced were varied. Anggrayani et al. (2018), based on their work conducted at dryland with E climate type (Oldeman classification) in Haharu Sub-district of Sumba Timur during January-March growing season 2017 reported that local cultivar gave higher pod yield $(1.589 \mathrm{t}$ $\mathrm{ha}^{-1}$ of dry pods in average) compared to that of Tuban cultivar with $1.460 \mathrm{t} \mathrm{ha}^{-1}$ of dry pods. Yield of local cultivar was also much higher than the yield of local cultivar in our result (0.901 $\mathrm{t} \mathrm{ha}^{-1}$ dry pods) (Table 4). Anggarayani's study (2018) highlighted the superiority of local cultivar over Tuban cultivar, with the absence of information on the original place of seed grower for that local cultivar used. These studies summarized that each cultivar had specific adaptation to a certain location.

\section{Yield components}

The average pod yields in Laipori and Palakahembi were not significantly different as the number of plant population at harvesting time was also similar even though the mature pods yield plant $^{-1}$ was significantly higher in Laipori. This higher mature pod weight plant $^{-1}$ would be contributed by bigger seed size (Table 5). The similar dry pod yields at both locations would probably as a result of similar farm inputs applied, amount of rainfall, and agroecological conditions, since unpredictable rainfall, variation of farm inputs, crop diseases were the major factors affecting groundnut yield (Kebede and Getahun 2017).

The study conducted by Mau et al. (2014) in Rote and Timor Islands, NTT Province revealed higher number of pods plant $^{-1}$ and seed size (100-seed weight) of Bison, Gajah, and Kancil cultivars compared to the current study. It was recognized that Mau et al. (2014) in that study applied wider plant spacing and higher dose of composite fertilizer compared to current study, which might be created better growing environment for peanut plants.

Shelling percentage which expresses an index of kernels weight to those of pods weight (Dapaah et al. 2014) differed significantly between Laipori and Palakahembi growing sites (Table 5). Despite significant difference in shelling percentage and mature pod yield plant ${ }^{-1}$ between those two sites, dry pods ha ${ }^{-1}$ was not significantly different between the two sites (Table 5).

Table 5. Pod yield and yield components of 11 cultivars grown in two sites. Sumba Timur, 2017

\begin{tabular}{|c|c|c|c|c|c|c|}
\hline Factor & $\begin{array}{l}\text { Dry pod yield } \\
\left(\mathrm{t} \mathrm{ha}^{-1}\right)\end{array}$ & $\begin{array}{c}\text { No of harvested } \\
\text { plants }\end{array}$ & $\begin{array}{c}\text { Mature pods } \\
\text { weight (g plant } \\
1 \text { ) }\end{array}$ & $\begin{array}{l}\text { Kernel yield } \\
\left(\text { g plant }^{-1}\right)\end{array}$ & $\begin{array}{l}100 \text { seeds } \\
\text { weight }(\mathrm{g})\end{array}$ & $\begin{array}{c}\text { Shelling } \\
\text { percentage }(\%)\end{array}$ \\
\hline \multicolumn{7}{|l|}{ Site } \\
\hline Laipori & 1.826 & 252 & $16.3 \mathrm{a}$ & 8.8 & 45.8 & $53.5 \mathrm{~b}$ \\
\hline \multirow[t]{2}{*}{ Palakahembi } & 1.720 & 214 & $11.4 \mathrm{~b}$ & 7.9 & 42.4 & $68.9 \mathrm{a}$ \\
\hline & ns & ns & $*$ & ns & $\mathrm{ns}$ & $* *$ \\
\hline \multicolumn{7}{|l|}{ Cultivar } \\
\hline L. Sandel & $0.901 \mathrm{f}$ & $123 \mathrm{~b}$ & $15.4 \mathrm{ab}$ & 9.4 & $45.9 \mathrm{bc}$ & $62.4 \mathrm{a}$ \\
\hline Bison & $1.861 \mathrm{cde}$ & 249 a & $12.2 \mathrm{bcd}$ & 7.4 & $40.1 \mathrm{~d}$ & $62.5 \mathrm{a}$ \\
\hline Gajah & $1.697 \mathrm{de}$ & $262 \mathrm{a}$ & $13.4 \mathrm{bcd}$ & 7.6 & $48.2 \mathrm{ab}$ & $58.5 \mathrm{a}$ \\
\hline Hypoma 1 & $2.313 \mathrm{a}$ & $262 \mathrm{a}$ & 13.9 abcd & 8.3 & $53.0 \mathrm{a}$ & $61.3 \mathrm{a}$ \\
\hline Hypoma 2 & $1.573 \mathrm{e}$ & $221 \mathrm{a}$ & $14.5 \mathrm{abc}$ & 8.9 & $46.9 \mathrm{~b}$ & $60.6 \mathrm{a}$ \\
\hline Kancil & $2.238 \mathrm{ab}$ & 249 a & $14.2 \mathrm{abc}$ & 8.5 & $47.3 \mathrm{~b}$ & $61.7 \mathrm{a}$ \\
\hline Kelinci & $2.174 \mathrm{abc}$ & $254 \mathrm{a}$ & $12.4 \mathrm{bcd}$ & 7.2 & $26.7 \mathrm{e}$ & $57.6 \mathrm{a}$ \\
\hline Takar 1 & $1.626 \mathrm{de}$ & 229 a & $17.7 \mathrm{a}$ & 10.5 & $52.8 \mathrm{a}$ & $60.1 \mathrm{a}$ \\
\hline Talam 1 & $1.591 \mathrm{de}$ & $228 \mathrm{a}$ & $12.9 \mathrm{bcd}$ & 7.5 & $43.9 \mathrm{bcd}$ & $59.4 \mathrm{a}$ \\
\hline Talam 2 & $1.926 \mathrm{bcd}$ & $261 \mathrm{a}$ & $11.2 \mathrm{~cd}$ & 7.1 & $39.1 \mathrm{~d}$ & $65.6 \mathrm{a}$ \\
\hline Tuban & $1.603 \mathrm{de}$ & $230 \mathrm{a}$ & $15.1 \mathrm{~d}$ & 9.5 & $41.0 \mathrm{~cd}$ & $63.9 \mathrm{a}$ \\
\hline Average & 1.773 & 233 & 13.9 & 8.4 & 44.1 & 61.2 \\
\hline DMRT & $*$ & $*$ & $*$ & ns & $*$ & $\mathrm{~ns}$ \\
\hline
\end{tabular}

Numbers in each column in each treatment followed by similar letters did not significantly different, $*, * *$ significantly different at $5 \%$ and $1 \%$, ns: non-significant 
The highest pod yield Hypoma 1 was supported by its bigger seed size and higher mature pods weight plant ${ }^{-1}$. The lowest pod yield ha $^{-1}$ was obtained by local cultivar of Sandel. This low pod yield was certainly caused by the lowest plant population and seed size even though the weight of mature pods plant ${ }^{-1}$ was reasonably high (Table 5 ). This low plant population of Sandel cultivar was the result of low seed germination; even it had been sown twice. Cultivar Kancil and Kelinci were quite superior in pod yields and it was ultimately based on high number of plant population, and to lesser extent by mature pods yield plant $^{-1}$, but not by seed size (Table 5). Cultivar Takar 1, however, had the lowest pod yield ha ${ }^{-1}$ although its seed size and mature pod yield plant ${ }^{-1}$ were the highest among the tested cultivars. It could probably be caused by its low number of harvested plants, based on the reason that peanut is a non-tillering plant and therefore pod yield is very dependent on its plant population. Konlan et al. (2013) discussed that the addition of plant numbers means increasing plant population resulting in higher number of pods and later on pod yield. Increasing plant density up to certain population was followed by increasing pod, haulm, and seed yields. The further increase of plant density, however, did not give any yield increase. This phenomenon also occurs in Virginia type with 120-day maturity and Spanish type with 95-100 day maturity (Dappaah et al. 2014).

Shelling percentage ranged from 58.5 to $65.6 \%$ with Gajah and Talam 2 exhibited the lowest and highest percentage, respectively. This result was in accordance with the work done under dry climate in Ghana where around $70 \%$ of peanut areas are under savanna ecology
(Oteng-Frimpong et al. 2017). In the present study, location served as the dominant contributor for shelling percentage variation (Table 2). This result, however, was different from that obtained by Yol et al. (2018) who reported that the $\mathrm{G} \times \mathrm{L}$ highly influenced shelling percentage. In addition, Yol et al. (2018) reported that shelling percentage of var. fastigiata ranged from $45-72 \%$ under dry environments with monthly rainfall $<40 \mathrm{~mm}$ during 4 months growing season in Turkey with typical Mediterranean climate conditions.

\section{Vegetative growth}

Fresh haulm weight and plant height were significantly influenced by the site where the crops grew, while the number of branches was ultimately influenced by genotype (Table 3). These fresh haulm weights and plant heights in Laipori were higher than those in Palakahembi sites. The dominance of location factor on plant height variation was supported by the data of each cultivar obtained from MET that were conducted under optimum water conditions. It was shown that all cultivars in the current experiment grew shorter than those obtained from MET (Table 6). The fresh haulm yield was affected by location. Certainly, the location factor contributed to $74.5 \%$ of haulm yield variation (Table 3). The Laipori site gave higher fresh haulm yield than Palahembi. The results indicated that haulm weight and plant height were governed by environmental conditions. Better responses of the crops to environmental conditions were expressed by better growth (Table 6).

Table 6. Fresh haulm weight, number of branches, plant height and number of mature pods per plant averaged from two sites. Sumba Timur, 2017

\begin{tabular}{|c|c|c|c|c|c|c|}
\hline \multirow[b]{2}{*}{ Factor } & \multirow{2}{*}{$\begin{array}{l}\text { Fresh haulm } \\
\text { yield }\left(\mathbf{t ~ h a}^{-1}\right)\end{array}$} & \multirow[b]{2}{*}{$\begin{array}{c}\text { No of } \\
\text { branches }\end{array}$} & \multicolumn{2}{|c|}{ Plant height (cm) } & \multicolumn{2}{|c|}{ No of mature pods/plant } \\
\hline & & & $\begin{array}{c}\text { The current } \\
\text { experiment } * * \text { ) }\end{array}$ & $\begin{array}{c}\text { MET } \\
* * *)\end{array}$ & $\begin{array}{c}\text { The current } \\
\text { experiment } * *)\end{array}$ & $\begin{array}{c}\text { MET } \\
* * *) \\
\end{array}$ \\
\hline \multicolumn{7}{|l|}{ Location } \\
\hline Laipori & $7.886 \mathrm{a}$ & 6.7 & $31.9 \mathrm{a}$ & - & & \\
\hline Palakahembi & $\begin{array}{c}4.544 \mathrm{~b} \\
*\end{array}$ & $\begin{array}{l}5.9 \\
\text { ns }\end{array}$ & $\begin{array}{c}24.3 \mathrm{~b} \\
*\end{array}$ & - & & \\
\hline \multicolumn{7}{|l|}{ Cultivar } \\
\hline L. Sandel & 4.968 & $6.5 \mathrm{bcd}$ & 24.5 & & 9 & \\
\hline Bison & 6.128 & $5.8 \mathrm{cde}$ & 27.9 & $29.4-72.4$ & 11 & $9-47$ \\
\hline Gajah & 6.453 & $6.2 \mathrm{bcd}$ & 27.7 & 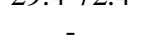 & 9 & - \\
\hline Hypoma 1 & 6.140 & $6.7 \mathrm{bc}$ & 27.9 & 38.4 & 9 & 27 \\
\hline Hypoma 2 & 5.833 & 6.0 cde & 30.1 & 35.5 & 10 & 30 \\
\hline Kancil & 6.053 & $5.6 \mathrm{de}$ & 27.4 & 54.9 & 10 & $15-20$ \\
\hline Kelinci & 7.077 & $5.1 \mathrm{e}$ & 27.6 & - & 10 & 15 \\
\hline Takar 1 & 6.185 & $7.9 \mathrm{a}$ & 29.1 & 68 & 11 & 24 \\
\hline Talam 1 & 7.250 & $7.0 \mathrm{~b}$ & 29.3 & 42 & 9 & 27 \\
\hline Talam 2 & 6.965 & $6.0 \mathrm{cde}$ & 27.2 & 57.5 & 11 & 22 \\
\hline Tuban & 5.310 & $6.8 \mathrm{bc}$ & 30.4 & $45-60$ & 13 & $15-20$ \\
\hline \multirow[t]{2}{*}{ Average } & 6.215 & 6.3 & 28.1 & & & \\
\hline & ns & $*$ & $\mathrm{~ns}$ & & & \\
\hline
\end{tabular}

Note: Numbers in the same columnin each treatment followed by the same character did not significantly different. *): significantly different at 5\%, ns: non significant; **) obtained from the current research; ***) MET: Multi Environment Testings (Balitkabi 2016) 
Table 7. Correlation between pod yield and yield components of peanut cultivars grown in two sites. Sumba Timur, February-May 2017

\begin{tabular}{|c|c|c|c|c|c|c|c|c|c|c|c|}
\hline & NB & PH & FHW & NHP & FPW & DPW & NMP & SP & $100 S$ & KY & PY \\
\hline NB & - & & & & & & & & & & \\
\hline $\mathrm{PH}$ & $0.413 * *$ & - & & & & & & & & & \\
\hline FHW & & $0.576^{* *}$ & - & & & & & & & & \\
\hline NHP & & $0.373 * *$ & & - & & & & & & & \\
\hline FPW & & & $0.535 * *$ & $0.656 * *$ & - & & & & & & \\
\hline DPW & & & $0.455 * *$ & $0.686 * *$ & $0.957 * *$ & - & & & & & \\
\hline NMP & $0.457 * *$ & $0.246 * *$ & & & & & - & & & & \\
\hline SP & & $0.606^{* *}$ & $0.591 * *$ & $0.264 * *$ & & $0.368 * *$ & & - & & & \\
\hline $100 \mathrm{~S}$ & $0.470 * *$ & & & & & & & & - & & \\
\hline KY & $0.633 * *$ & $0.286^{*}$ & & & & & $0.756 * *$ & & $0.487 * *$ & - & \\
\hline PY & $0.683 * *$ & $0.536 * *$ & $0.296^{*}$ & & & & $0.623 * *$ & $-0.344 * *$ & $0.496 * *$ & $0.887 * *$ & - \\
\hline
\end{tabular}

Note: No of branches, PH: plant height, FHW: fresh haulm weight/ha, NHP: no of harvested plants ha ${ }^{-1}$, FPW: fresh pods weight ha ${ }^{-1}$, DPW: dry pod weight ha ${ }^{-1}$, NMP: no of mature pods plant $^{-1}$, SP: shelling percentage, 100S: 100-seed weight, PY: pod yield plant ${ }^{-1}$, KY: kernel yield plant ${ }^{-1}, *$, ** significantly different at $5 \%$ and $1 \%$

The number of branches of 11 cultivars tested ranged from 5.0 to 6.9 with the mean was 6.3. These were in line with the study results of Yol et al. (2018) who reported the average number of branches of variety fastigiata ranged from 4.0-14.0. The experiment applied 10 Spanish and one Valencia type (market types) which both types belonged to fastigiata (Suassuna et al. 2015).

The farmers in Sumba Timur usually keep the fresh haulm in the field after separating the pods from the plants. The fresh green biomass of peanut residues (leaves, stems, pegs, small portion of taproots) is then naturally decomposes on the soil surface. Placing the fresh haulms on the soil surface under semi-arid climatic condition gave several benefits such as reduced soil erosion, enhanced water retention, increased organic matter content, longer mass loss, less carbon and nitrogen loss at certain period of time, whereas incorporating peanut residues into the soil accelerated decomposition (Mulvaney et al. 2017).

\section{Correlation among variables}

Fresh pods yield $\left(\mathrm{t} \mathrm{ha} \mathrm{h}^{-1}\right)$ was positively correlated with fresh haulm weight $\left(\mathrm{t} \mathrm{ha}^{-1}\right)$ and number of harvested plants $\mathrm{ha}^{-1}$ (plant population). In addition, dry pods yield $\left(\mathrm{t} \mathrm{ha}^{-1}\right)$ was positively correlated with fresh haulm weight $\left(\mathrm{t} \mathrm{ha}^{-1}\right)$, number of harvested plants $\mathrm{ha}^{-1}$, and shelling percentage (Table 7). Among these three parameters, dry pods yield had the strongest correlation with number of harvested plants $(r=0.686)$. The presence of these correlations was also reported by Sabiel et al. (2014). The significant positive correlation between haulm yield and pod yield was reported by Özyiğit and Bilgen (2013), i.e., genotype with the highest haulm yield also produced the highest dry pods yield under Mediterranean dry climate in Turkey.

Kernel yield plant $^{-1}$ was found to be positively correlated with seed size or 100-seeds weight, and number of pods plant ${ }^{-1}$. Pod yield plant ${ }^{-1}$ showed positive correlation with kernels yield plant ${ }^{-1}$, seed size, shelling percentage, and number of mature pods plant $^{-1}$. These results were in line with those of Yadlapalli (2014) and Zongo et al. (2017), indicating that plants with a higher number of mature pods plant ${ }^{-1}$, heavier mature pods plant ${ }^{-1}$, and bigger seed size produced a higher seed yield. This result is similar to that reported by Dapaah et al. (2014) and Dabessa et al. (2016). Pod yield plant $^{-1}$ was positively correlated with number of pods plant ${ }^{-1}$, kernel yield plant ${ }^{-1}$, and seed size. These significant and positive correlations were also reported by Yol et al. (2018). In addition, Ganvit and Jagtap (2018) added the presence of highly significant and positive correlation between pod yield plant $^{-1}$ and shelling percentage. They further mentioned that kernel yield plant ${ }^{-1}$, number of mature pods plant $^{-1}$ showed high and positive direct effect on pod yield plant ${ }^{-1}$. In more detail, Hampannavar et al. (2018) reported that kernel yield plant $^{-1}$ had a high direct effect on dry pod yield plant ${ }^{-1}$. Yadlapalli (2014) emphasizes the positive direct effect of number pods plant $^{-1}$ on pod yield plant $^{-1}$, followed by, respectively, 100-seeds weight, number of branches plant ${ }^{-1}$, and days to $50 \%$ flowering.

Number of branches had a positive correlation with plant height, while Yoi et al. (2018) reported a negative correlation between the two traits. Despite this contradicting result, the current research also revealed that number of branches had a positive correlation with yield components i.e., number of pods plant ${ }^{-1}$, pod yield plant ${ }^{-1}$, kernel yield plant $^{-1}$, and 100-seed weight. This statement was supported by the work conducted by Yadlapalli (2014). Plant height was found to be positively correlated with kernel yield plant ${ }^{-1}$. Zongo et al. (2017) also found positive correlation between plant height kernel yield plant ${ }^{-}$ ${ }^{1}$ and so did between the plant height and 100-seed weight.

In conclusion, the improved cultivars produced higher pods and haulms yields as compared to the local cultivar under the climatic condition of dryland with semi-arid climate condition of Sumba Timur. On the other side, pod yields of improved cultivars under the present study were lower than their yield potentials. The improved cultivars Hypoma 1 and Kancil could be proposed to the farmers in Sumba Timur because of their high pod yields and organic matter content in soils after the cultivars were harvested. Low pod yield of local Sandel was mainly caused by low plant population at harvest, despite its superior mature pods yield plant $^{-1}$ and seed size. 


\section{ACKNOWLEDGEMENTS}

The authors would like to thank Cipto Prahoro and Yermias Bombo for organizing the field trials, Dian Adi Anggraeni Elisabeth, for putting the manuscript into the journal template, and Ms. Irin for helping in preparing the graphs. The authors very much appreciate The Ministry of Agriculture, Government of Indonesia who funded the experiments.

\section{REFERENCES}

Anggrayani S, Sebastian G, Purnomosidhi P, Suryasdi A, Ismawan IN Hanggawali N, Mulyoutami E, Rosthetko JM. 2018. Choosing managements of Growing Peanut as an Effort to Improve the Lives of Haharu. Indonesia Village Economical Development Series. Working Paper 277. World Agroforestry Centre (ICRAF) Southeast Asia Regional Program, Bogor. DOI: 10.5716/WP18004.PDF [Indonesian]

Arya SS, Salve AR, Chauhan S. 2016. Peanuts as functional food: a review. J Food Sci Technol 53 (1): 31-41.

Balitkabi [Balai Penelitian Tanaman Aneka Kacang dan Umbi]. 2016. The Description of Improved Cultivars of Legumes and Tuber Crops. Indonesian Legumes and Tuber Crops Research Institute. Indonesian Agency for Agricultural Research and Development, Malang [Indonesian]

BPS Sumba Timur. 2012. Sumba Timur in Figures 2012. BPS Statistics of Sumba Timur District, Waingapu.

BPS Sumba Timur. 2013. Sumba Timur in Figures 2013. BPS Statistics of Sumba Timur District, Waingapu.

BPS Sumba Timur. 2014. Sumba Timur in Figures 2014. BPS Statistics of Sumba Timur District, Waingapu.

BPS Sumba Timur. 2015. Sumba Timur in Figures 2015. BPS Statistics of Sumba Timur District, Waingapu.

BPS Sumba Timur. 2016. Sumba Timur in Figures 2016. BPS Statistics of Sumba Timur District, Waingapu.

BPS Sumba Timur. 2017. Sumba Timur in Figures 2017. BPS Statistics of Sumba Timur District, Waingapu.

BPS Sumba Timur. 2018. Sumba Timur in Figures 2018. BPS Statistics of Sumba Timur District, Waingapu.

Canavar Ö, Kaynak MA. 2010. Growing degree day and sunshine radiation effects on peanut pod yield and growth. African J Biotechnol 9 (15): 2234-2241.

Dabessa A, Alemu B, Abebe Z, Lule D. 2016. Genotype by environment interaction and kernel yield stability of groundnut (Arachis hypogaea L.) varieties in western Oromia, Ethiopia. J Agric Crops 2 (11): 113120.

Dapaah HK, Mohammed I, Awuah RT. 2014. Growth and yield performance of groundnuts (Arachis hypogaea L.) in response to plant density. Intl J Plant Genomics Soil Sci 3(9): 1069-1082.

Dariah A, Heryani N. 2014. Empowerment of sub-optimal dry land to support diversification and food security policy. Jurnal Sumberdaya Lahan (2016): 1-16. Special Edition. [Indonesian]

Ditjentan [Directorate General for Food Crops]. 2020. The development of harvesting areas, crop productivity and production of the main commodities of food crops. The Indonesian Ministry of Agriculture, Jakarta. [Indonesian]

Dolinassou S, Tchiagam JBN, Kemoral AD, Yanou NN. 2016. Genotype $\times$ environment interaction and kernel yield-stability of groundnut (Arachis hypogaea L.) in Northern Cameroon. J Appl Biol Biotechnol 4 (1): 001-007.

Ganvit RS, Jagtap PK. 2018. Character association and path co-efficien analysis studies for yield and its contributing traits in groundnut (Arachis hypogaea L.). Intl J Curr Microbiol Appl Sci 7 (11): 35663572 .

Hampannavar MR, Khan H, Temburne BV, Janila P, Amaregouds A. 2018. Genetic variability, correlation and path analysis studies for yield and yield attributes in groundnut (Arachis hypogaea L.). J Pharmacognosy and Phytochemistry 7 (1): 870-874.

Homann-Kee Tui S, van Royen A, Dube T, Kudita S, Chivenge P, Kondwakwenda A, Madzonge O, Masendeke D, Savemore NN, M Muhambi. 2012. Partnerships for Unlocking Potential in Groundnut
Value Chain in Zimbabwe. International Crops Research Insitute for the Semi-Arid Tropics.

Htoon W, Jogloy S, Vorasoot N, Toomsan B, Kaewpradit W, Puppala N, Patanothai A. 2014. Nutrient uptake and their contributions to yield in peanut genotypes with different levels of terminal drought resistance. Turkish J Agriculture and Forestry 38: 781-791.

Janila P, Nigam SN, Pandey MK, Nagesh P, Varshney RV. 2013. Groundnut improvement: use of genetic and genomic tools. Frontiers in Plant Science 4 (23): 16.

Kabede K, Getahun A. 2017. Adaptability and stability analysis of groundnut genotypes using AMMI model and GGE-biplot. J Crop Science and Biotechnology 20 (5): 343-349.

Katundu MA, Mhina ML, Mbeiyererwa AG, Kumburu NP. 2014. Socioeconomic factors limiting smallholder groundnut production in Tabora Region. Research Report 14/1. REPOA, Dar es Salaam.

Konlan S, Sarkodie-Addo J, Asare E, Kombiok MJ. 2013. Groundnut (Arachis hypogaea L.) varietas response to spacing in the Guinea savanna agro-ecological zone of Ghana: Growth and yield. Afr J Agric Res 8 (22): 2769-2777.

Koolachart R, Jogloy S, Vorasoot N, Wongkaew S, Holbrook CC, Jongrungklang N, Kesmala T, Patanothai A. 2013. Rooting traits of peanut genotypes with different yield responses to terminal drought. Field Crops Res 149: 366-376.

Mau YS, Ndiwa ASS, Arsa IGBA. 2014. Drought tolerance of Local Rote and check varieties of groundnut (Arachis hypogaea L.) under dry season in two locations in East Nusa Tenggara. Agrivita 36 (3): 268277.

Oteng-Frimpong R, Dakora FD. 2019. Multi environment testing for trait stability and $\mathrm{G} \times \mathrm{E}$ interaction on $\mathrm{N}_{2}$ fixation, plant development, and water-use efficiency of 21 elite groundnuts (Arachis hypogaea L.) genotypes in the Guinea savanna. Front Plant Sci 10 (1070): 12. DOI: 10.3389/fpls.2019.01070.

Oteng-Frimpong R, Konlan AP, Denwar NN. 2017. Evaluation of selected groundnut (Arachis hypogaea $\mathrm{L}$.) lines for yield and haulm nutritive quality traits. Intl J Agron 9: 7479309. DOI: 10.1155/2017/7479309.

Özyiğit Y, Bilgen M. 2013. Forage potential of some groundnut (Arachis hypogaea L.) cultivars. Romanian Agric Res 30: 57-63.

Prawiradipura BR, Lukiwati DR. 2014. The utilization of legumes and tuber food crops residues and by-products for animal feed. Proceedings of Seminar on Legumes and Tuber Crops Research Results. Indonesian Central Research Institute for Food Crops, Bogor. [Indonesian]

Purnomo J, Nugrahaeni N, Baliadi Y. 2019. Productivity of groundnut genotypes and their resistance to Ralstonia solanacearum bacteria wilt. Buletin Palawija 17 (2): 102-111. [Indonesian]

PUSDATIN [Pusat Data dan Sistem Informasi Pertanian]. 2016. Outlook Komoditas Pertanian Sub Sektor Tanaman Pangan: Kacang tanah. Kementerian Pertanian, Jakarta. [Indonesian]

Rahmianna AA, Pratiwi H, Harnowo D. 2015. Budidaya kacang tanah. In: Kasno A, Rahmianna AA, Mejaya IMJ, Harnowo D, Purnomo S (eds). Kacang Tanah. Inovasi Teknologi dan Pengembangan Produk. Monograf Balitkabi No. 15-2015. Balai Penelitian Tanaman Aneka Kacang dan Umbi. [Indonesian]

Sabiel SAI, Ismail MI, Abdalla E, Osman KA. 2014. Genetic variation of groundnut (Arachis hypogaea L.) genotypes in semi-arid zone. Sudan. Intl J Environ 3 (3): 16-23.

Savemore NN, Manjeru P, Ncube B. 2017a. Assessment of genotype $\times$ environment interaction and pod yield evaluation of groundnut (Arachis hypogaea L.) genotypes in Zimbabwe. Afr J Plant Sci 11 (3): 54-60.

Savemore NN, Manjeru P, Ncube B. 2017b. Pod yield stability and adaptation of groundnut (Arachis hypogaea L.) genotype evaluated in multi-environmental trials in Zimbabwe. Afr J Plant Sci 11 (5): 174184.

Séne LM. 2015. Connectivity as engine for productivity among smallholder peanut farmers in Senegal. Paper presented in International Conference of Agricultural Economists "Agriculture in an Interconnected World" held in Universita Dfgli Study, Milano, 814 August 2015.

Suassuna TMF, Suassuna ND, Moretzsohn MC, Bertioli SCML, Bertioli DJ, Medeiros EP. 2015. Yield, market quality and leaf spots partial resistance of interspecific oc peanut progenies. Crop Breed Appl Biotechnol 15: 175-180.

Variath MT, P Janila. 2017. Economic and academic importance of peanut. P. 7-26. In: Varshney RK, Pandey MK, Puppala N (eds.). The 
Peanut Genome. Compendium of Plant Genomes Series. Springer International Publishing, New York.

Yadlapalli S. 2014. Genetic variability and character association studies in groundnut (Arachis hypogaea L.). Intl J Plant Anim Environ Stud 4 (4): 298-300

Yol E, Furat S, Upadhyaya HD, Uzun B. 2018. Characterization of groundnut (Arachis hypogaea L.) collection using quantitative and qualitative traits in the Mediterranean Basin. J Integr Agric 17 (1): 63 75

Zongo A, Nana AT, Sawadogo M, Konate AK, Sankara P, Ntare BR, Desmae H. 2017. Variability and correlations among groundnut populations for early leaf spot, pod yield, and agronomic traits. Agronomy 7 (52): 11. DOI: 10.930/agronomy7030052. 